\title{
Frequency of fungicide-resistant Botrytis cinerea populations isolated from 'Thompson Seedless' table grapes in the Central Valley of Chile
}

\author{
Marcela Esteriol ${ }^{1}$, Charleen Copier ${ }^{1}$, Andrea Román², María José Araneda ${ }^{1}$, \\ Mauricio Rubilar', Isabel Pérez ${ }^{1}$, and Jaime Auger ${ }^{1}$ \\ ${ }^{1}$ Universidad de Chile, Facultad de Ciencias Agronómicas, Departamento de Sanidad Vegetal, Laboratorio \\ de Fitopatología Frutal y Molecular. Santiago, Chile. Código Postal 8820808. \\ ${ }^{2}$ Centro de Desarrollo de Tecnología para la Reducción y Racionalización de Agroquímicos \\ (CEDETERRA). ESPOCH. Panamericana Sur km 1/2, Riobamba, Ecuador. Código Postal EC060155.
}

\begin{abstract}
M. Esterio, C. Copier, A. Román, M.J. Araneda, M. Rubilar, I. Pérez, and J. Auger. 2017. Frequency of fungicide-resistant Botrytis cinerea populations isolated from 'Thompson Seedless' table grapes in the Central Valley of Chile. Cien. Inv. Agr. 44(3): 295-306. During the 2013 and 2014 growth seasons, 526 single spore isolates of Botrytis cinerea were collected from naturally infected 'Thompson Seedless' table grape flowers from fifteen orchards in three regions of the Central Valley of Chile. The isolates were tested for resistance to azoxystrobin, boscalid, fenhexamid, fludioxonil and pyrimethanil. Among the 526 isolates, 106 (20.15\%) were sensitive to all fungicides tested; from north to south, the frequency of sensitive isolates in the regions of Valparaiso, Metropolitana and O'Higgins ranged from $48.15 \%$ to $21.1 \%$ and $5.88 \%$, respectively. Four hundred and twenty isolates $(79 \%)$ showed resistance to single or multiple fungicides, $134(25.4 \%)$ were simultaneously resistant to azoxystrobin and pyrimethanil. No fludioxonil-resistant isolates were found, indicating that fludioxonil has great potential for gray mold control in table grapes in Chile. From sixty randomly selected $B$. cinerea isolates, only the azoxystrobin-resistant isolates carried the G143A point mutation; according to the cytochrome $\mathrm{b}(c y t b)$ gene structure, the third intron Bcbi-143/144 was only detected in the azoxystrobin-sensitive isolates. The $\mathrm{H} 272 \mathrm{R}$ and $\mathrm{H} 272 \mathrm{Y}$ point mutations in the succinate dehydrogenase subunit B $(s d h B)$ gene were associated only with the boscalid-resistant isolates. The F412S and F412V point mutations were found in the sequenced erg27 gene of randomly selected fenhexamid-resistant isolates. These results contribute to the knowledge of $B$. cinerea fungicide resistance for table grape vine crops in Central Chile, particularly for the development of multiple-resistance and the associated resistance mechanisms of azoxystrobin, boscalid and fenhexamid-resistant isolate populations. Antiresistance strategies are discussed in a general manner.
\end{abstract}

Keywords: Anilino-pyrimidines, gray mold, multiple-resistance, phenylpyrroles, quinone outside inhibitors, sterol biosynthesis inhibitors class III, succinate dehydrogenase inhibitors.

\section{Introduction}

Grape vines, one of the major Chilean fruit crops, are mostly cultivated in the Central Valley because of its favorable regional agroecological conditions.

Received December 27, 2016. Accepted October 10, 2017. Corresponding author: mesterio@uchile.cl
The vast majority of table grapes grown in Chile are exported to the northern hemisphere. Vitis vinifera cv. 'Thompson Seedless' ('Th. Seedless') ranks as the second most important commercial grape variety, with a total crop value of US\$ 234 million (ODEPA, 2016). However, since most table grapes are trained onto overhead arbors 
and due to the frequent changes to cool and wet weather conditions in the last growing seasons, 'Th. Seedless' table grape growers and fruit export traders have been affected by important pre- and postharvest Botrytis gray mold outbreaks. In fact, grape production decreased from 170,194 tons in 2012 to 132,465 tons in 2014 (ODEPA, 2016). In Chile, $B$. cinerea has caused blossom blight during the bloom period and fruit rot during the pre- and postharvest periods (Latorre et al., 2002).

The application of fungicide sprays from blooming until harvest is the essential measure taken to reduce Botrytis infection-related losses. However, B. cinerea can develop resistance to commonly used fungicides, an ability that is partly due to its relatively large genetic diversity and enormous capacity for asexual reproduction by means of conidia (Leroux et al., 2002).

Resistance to recently introduced fungicides, such as anilino-pyrimidines (APs), phenylpyrroles (PPs) and sterol biosynthesis inhibitors class III (SBIs-III; hydroxyanilides), has also been reported (Leroux et al. 2002; Moyano et al., 2004; Weber, 2010). Moreover, field resistance to novel succinate dehydrogenase inhibitor (SDHI) fungicides was detected soon after their introduction (Bardas et al., 2010). Molecular characterization of $B$. cinerea isolates that were sensitive or resistant to single-site fungicides showed the involvement of major genes of the fungus and a strong association between resistant phenotypes and point mutations (single nucleotide polymorphisms, SNPs) (De Miccolis Angelini et al., 2012). These results have been observed for several groups of fungicides, including SDHIs (Yin et al., 2012), SBIs-III (Fillinger et al., 2008) and quinone outside inhibitors (QoIs) (De Miccolis Angelini et al., 2012; Ishii et al., 2009).

During the last decade, pyrimethanil, azoxystrobin, boscalid, fenhexamid and fludioxonil fungicides have been used extensively to control gray mold disease in table grapes in Chile, and fungicide resistance of $B$. cinerea has been reported (Este- rio et al., 2007, 2012, 2015; Latorre et al., 2002; Piqueras et al., 2014). We hypothesized that the frequency of multiple-resistance in $B$. cinerea populations would increase; thus, it would be crucial to monitor such frequency in table grape orchards to evaluate the risk of infection for specific areas and growing conditions and elaborate appropriate anti-resistance strategies. Therefore, the objectives of the present study were as follows: i) to screen the sensitivity of $B$. cinerea populations isolated from 'Th. Seedless' table grapes to azoxystrobin, boscalid, fenhexamid, fludioxonil and pyrimethanil and assess their resistance frequencies to these fungicides and ii) to investigate the point mutations associated with QoI, SDHI and SBI-III resistance in azoxystrobin-, boscalid- and fenhexamid-resistant isolates.

\section{Materials and methods}

Collection of B. cinerea isolates.

To detect fungicide resistance in B. cinerea, 'Th. Seedless' naturally infected flowers were sampled during the 2013 and 2014 growing seasons from fifteen orchards in three regions of the Central Valley of Chile (Valparaiso, Metropolitana and O'Higgins). Two hundred flowers ( $\mathrm{n}=50 /$ plate) per orchard were incubated for 3-5 days on water agar medium at $25^{\circ} \mathrm{C}$. Mycelia from the colonized flowers were transferred to potato dextrose agar medium and incubated at $22{ }^{\circ} \mathrm{C}$ under a diurnal regime (12-h light/12-h dark light cycle). Pure cultures were transferred to malt extract agar (MEA) medium and incubated at $20^{\circ}$ C. B. cinerea isolates were then single-spore cultured on MEA medium, and mycelia were stored in $15 \%$ glycerol at $-80{ }^{\circ} \mathrm{C}$.

\section{In vitro fungicide assays.}

In vitro responses of $B$. cinerea isolates to azoxystrobin, boscalid, fenhexamid, fludioxonil and pyrimethanil were determined. The $\mathrm{EC}_{50}$ values 
(the effective concentrations that inhibited the conidial germ tube growth by $50 \%$ relative to the control) of fenhexamid (Teldor ${ }^{\circledR} 50 \% \mathrm{WP}$, Bayer CropScience AG, Monheim, Germany) and fludioxonil (Scholar ${ }^{\circledR} 23 \%$ SC, Syngenta S.A., Monthey, Switzerland), were determined by spotting aliquots $(20 \mu \mathrm{l})$ of suspension containing $5 \times 10^{5}$ conidia $\mathrm{ml}^{-1}$ on $1 \%$ MEA medium, either without or amended with increasing concentrations of fungicide: $0,0.01,0.1,1,10$ and $100 \mu \mathrm{g} \mathrm{ml}^{-1}$. For the QoI fungicide azoxystrobin (Quadris ${ }^{\circledR}, 25 \%$ CS, Syngenta S.A., Monthey, Switzerland), the alternative oxidase inhibitor salicylhydroxamic acid (SHAM, Sigma-AldrichLaboratories Inc., St. Louis, USA) was added to the MEA medium at a concentration of $100 \mu \mathrm{g} \mathrm{ml}^{-1}$. For the pyrimethanil (Scala ${ }^{\circledR} 40 \%$ SC, Bayer CropScience AG, Monheim, Germany) assay, $0.5 \%$ sucrose agar medium was used instead of the MEA medium to exclude amino acids, and for the SDHI fungicide boscalid (Cantus ${ }^{\circledR}$ 50\% WG, BASF SE, Ludwigshafen, Germany), $0.5 \%$ yeast extract agar medium was used to prevent the interference of sugars with the assay (Weber and Hahn, 2011). For each isolate and fungicide concentration tested, growth was measured after 16 h using a 6331 Nauborn Wetzlar microscope (Will@, Germany) fitted with a 10x objective and an eyepiece reticule at 100x final magnification. Each test was performed 2-3 times. The $\mathrm{EC}_{50}$ values were calculated by regressing the relative inhibition of conidial germination against the $\log _{10}$-transformed fungicide concentrations. To measure cross-resistance between pairs of fungicides, the correlation coefficients $(r)$ of the $\mathrm{EC}_{50}$ values of all fungicides were calculated. The $\mathrm{EC}_{50}$ values were $\log _{10}$ transformed before analysis. All statistical analyses were conducted using InfoStat statistical software V. 2014 (Di Rienzo et al., 2014). The fungicide resistance or sensitivity of the isolates was tested as described previously using the following discriminatory fungicide concentrations (per ml): $100 \mathrm{mg}$ of azoxystrobin supplemented with SHAM, 10 $\mathrm{mg}$ of boscalid, $1 \mathrm{mg}$ of fenhexamid, $1 \mathrm{mg}$ of fludioxonil and $10 \mathrm{mg}$ of pyrimethanil (Weber and Hahn, 2011).

\section{Genetic characterization.}

SNPs were searched in specific key genes of resistance to QoIs, SDHIs and SBI-IIIs in B. cinerea isolates. For all assays, DNA was extracted from mycelium as previously described by Veloukas et al. (2011).

Analysis of a partial sequence of the cytochrome $b$ (cyt b) gene from azoxystrobin-resistant $\left(A z O^{R}\right)$ and azoxystrobin-sensitive $\left(A z O^{S}\right)$ isolates.

The PCR primers cytb-BcF and cytb-BcR (Table 1) were used to amplify a $c y t b$ gene fragment containing the codons 137 (carrying the G137R mutation) and 143 (carrying the G143A mutation) from randomly selected $\mathrm{Azo}^{\mathrm{R}}$ and $\mathrm{Azo}^{\mathrm{S}}$ B. cinerea isolates. The primers cytb129-F and cytb129-R (Table 1) were used to amplify a $978 \mathrm{bp}$ fragment of the cyt $b$ gene containing the codon 129 (carrying the F129L mutation). Additionally, as a specific diagnostic tool, the allele-specific PCR primers BcAR-F and BcAR-R (Table 1) were used to amplify a $260 \mathrm{bp}$ fragment containing the G143A mutation only on $\mathrm{Azo}^{\mathrm{R}}$ B. cinerea isolates. The PCR amplifications were conducted using the parameters described by Jiang et al. (2009). The PCR products were examined by electrophoresis on a $1.5 \%$ agarose gel in $1 \times$ Tris-acetate-EDTA (TAE) buffer (De Miccolis Angelini et al., 2012).

DNA sequence analysis of the succinate dehydrogenase subunit $B$ (sdhB) gene from boscalid-resistant $\left.\left(B^{R}\right)^{R}\right)$ and boscalid-sensitive $\left(\right.$ Bos $\left.^{S}\right)$ isolates.

A fragment containing codons 225 and 272 in the $s d h B$ gene was amplified from randomly selected $\operatorname{Bos}^{\mathrm{R}}$ and $\mathrm{Bos}^{\mathrm{S}} B$. cinerea isolates using the IpBcBeg and IpBcEnd 2 primers (Table 1), and the PCR products were sequenced and compared with the $s d h B$ gene reference sequence (Gene ID: 5428850 , GenBank). For the detection of each of the five polymorphisms, a primer-introduced 
Table 1. PCR primers used in this study

\begin{tabular}{|c|c|c|c|}
\hline Gene & Primer pair & Sequences $\left(5^{\prime}-3^{\prime}\right)$ & PCR product (bp) \\
\hline \multirow[t]{4}{*}{ erg27 } & Fnx.42 & GGTATTCCTCCGATTGTGGA & 1156 \\
\hline & Fnx.1197 & TAAAGGCATCAGCTCGTGTG & \\
\hline & Fnx.844 & GAGCTGAGATCTTGGGGATG & 1164 \\
\hline & Fnx.2007 & TGTGTATGATGTACGGCCAAC & \\
\hline \multirow[t]{6}{*}{$c y t b$} & BcAR-F & GGCAAATGTCACTGTGAGC & 260 \\
\hline & BcAR-R & ACCATCTCCATCCACCATACCT & \\
\hline & cytb-BcF & TAAAGTGGTATAACCCGACGG & $1768 / 564$ \\
\hline & cytb-BcR & СCATCTCCATCCACCATACCT & \\
\hline & cytb129-F & GCATAAAGCATTGGGGCTAA & 978 \\
\hline & cytb129-R & CCGTCTGGCGTCACTATAAAT & \\
\hline \multirow[t]{10}{*}{$s d h B$} & IpBcBeg & CCACTCCTCCATAATGGCTGCTCTCCGC & 953 \\
\hline & IpBecEnd2 & CTCATCAAGCCCCCTCATTGATATC & \\
\hline & $\mathrm{H} 272 \mathrm{~L}$ & GGCAGCTTTGGATAACAGCATGAGTTTGTACAGAGATC & 120 \\
\hline & $\mathrm{H} 272 \mathrm{R}$ & GGCAGCTTTGGATAACAGCATGAGTTTGTACAGATGGC & 120 \\
\hline & $\mathrm{H} 272 \mathrm{Y}$ & GGCAGCTTTGGATAACAGCATGAGTTTGTACAGATAT & 120 \\
\hline & H272-rev & GCCATTTCCTTCTTAATCTCCGC & -- \\
\hline & N230I-fw & GACCCAGCACCAGAAGGAAAAG & 150 \\
\hline & N230I-rev & GATAGCTGGTCCCAAGTACTCCTCACGG & \\
\hline & $\mathrm{P} 225 \mathrm{~F}-\mathrm{fw}$ & GTATTCTCTGCGCATGCTGCTCGACATCAAGC & 144 \\
\hline & P225-rev & AAGCTGCCTTACGTTCTTCC & \\
\hline
\end{tabular}

restriction analysis polymerase chain reaction (PIRA-PCR) technique was used (Veloukas et al., 2011). For this purpose, the PCR products were amplified with primer pairs $\mathrm{P} 225 \mathrm{~F}-\mathrm{fw}$ and P225-rev, N230I-fw and N230I-rev, H272L-fw and H272-rev, H272R-fw and H272-rev, and H272Yfw and H272-rev (Table 1) and digested with the enzymes HindIII, BamHI, BglII, HhaI, and EcoRV, respectively. Digestion solutions consisted of 5 $\mu \mathrm{l}$ of PCR product, 0.5 unit of each enzyme and 1 unit of the respective enzyme buffer in a total reaction volume of $10 \mu \mathrm{l}$. Digestions were performed overnight at $37^{\circ} \mathrm{C}$. The PCR and digested product were separated by electrophoresis on a $2 \%$ agarose gel in $1 \times$ TAE buffer and visualized after SYBR ${ }^{\circledR}$ Safe DNA gel staining under UV light (Veloukas et al., 2011).
Analysis of erg27 gene sequences from fenhexamid-resistant $\left(\mathrm{Fen}^{R}\right)$ and fenhexamidsensitive $\left(\mathrm{Fen}^{\mathrm{S}}\right)$ isolates.

Randomly selected $\mathrm{Fen}^{\mathrm{R}}$ and $\mathrm{Fen}^{\mathrm{S}}$ B. cinerea isolates were analyzed for specific key genes of resistance to SBI-IIIs. PCR amplification was performed using two specific primer pairs to amplify partially overlapping fragments of the erg27 gene of B. cinerea: Fnx.42 and Fnx.1197, and Fnx.844 and Fnx.2007 (Table 1). PCR amplifications were conducted using the parameters described by De Miccolis Angelini et al. (2014).

All PCR products $\left(\mathrm{Azo}^{\mathrm{R}}, \mathrm{Bos}^{\mathrm{R}}\right.$ and $\left.\mathrm{Fen}^{\mathrm{R}}\right)$ were sequenced by an external service (Macrogen USA 
Corp, DNA Sequencing Service, Maryland, USA), and the DNA sequence analysis was performed using the software Vector NTI suite 7.

\section{Results}

Collection of $\mathrm{B}$. cinerea isolates.

A total of 526 monosporic $B$. cinerea isolates were obtained from the fifteen 'Th. Seedless' orchards sampled (Valparaiso $n=171$; Metropolitana $n=180$; O’Higgins n=175).

\section{Fungicide resistance frequency distribution among locations.}

Fungicide resistance monitoring of the 526 isolates, based on discriminatory concentrations of azoxystrobin, boscalid, fenhexamid, fludioxonil and pyrimethanil, identified 14 resistant phenotypes. Among the 526 isolates, 106 (20.15\%) were sensitive to all fungicides tested. Resistance to single fungicides was distributed as follows: 35 $(6.65 \%)$ isolates were resistant to azoxystrobin, $14(2.66 \%)$ to boscalid, 20 (3.8\%) to fenhexamid, and $35(6.65 \%)$ to pyrimethanil. Resistance to two fungicides was distributed as follows: 134 (25.4\%) isolates were resistant to azoxystrobin and pyrimethanil, $29(\% 5.5 \%)$ to azoxystrobin and fenhexamid, $10(1.9 \%)$ to azoxystrobin and boscalid, $8(1.5 \%)$ to pyrimethanil and fenhexamid, and $6(1.14 \%)$ to pyrimethanil and boscalid, and only one $(0.19 \%)$ isolate was resistant to fenhexamid and boscalid. Resistance to three or more fungicides was distributed as follows: 68 (12.9\%) isolates were resistant to fenhexamid, azoxystrobin and pyrimethanil, 27 (5.1\%) to boscalid, azoxystrobin and pyrimethanil, and 8 (1.52\%) to azoxystrobin, boscalid, fenhexamid and pyrimethanil (Fig. 1). Among the three regions in Central Chile from north to south, Valparaiso $(n=171)$, Metropolitana $(n=180)$ and
O'Higgins ( $\mathrm{n}=175)$, the frequencies of sensitive isolates to all fungicides were $48.15 \%, 21.11 \%$ and $5.88 \%$, respectively. From north to south, the frequency of resistant isolates to azoxystrobin, boscalid, fenhexamid and pyrimethanil ranged from $31.6 \%$ to $86.3 \%, 11.1 \%$ to $18.85 \%, 26.3 \%$ to $36.5 \%$, and $30.4 \%$ to $73.14 \%$, respectively. No fludioxonil-resistant isolates were found among the 526 isolates tested.

To investigate the point mutations associated with QoI, SDHI and SBI-III resistance for azoxystrobin, boscalid and fenhexamid, 30 each of $\mathrm{Azo}^{\mathrm{R}}, \mathrm{Azo}^{\mathrm{S}}$, $\mathrm{Bos}^{\mathrm{R}}, \mathrm{Bos}^{\mathrm{S}}, \mathrm{Fen}^{\mathrm{R}}$ and $\mathrm{Fen}^{\mathrm{S}}$ B. cinerea isolates were randomly selected.

Molecular characterization of a partial sequence of the cyt $b$ gene from randomly selected $A z O^{R}$ and $A z O^{S} B$. cinerea isolates.

Two types of $c y t b$ gene fragments were obtained from the PCR amplification with the primers cytb$\mathrm{BcF}$ and cytb-BcR in all the $B$. cinerea isolates tested. Fourteen (23.3\%) isolates amplified a $c y t b$ gene fragment of $1768 \mathrm{bp}$ containing four introns (Bcbi-67/68, Bcbi-131/132, Bcbi-143/144 and Bcbi-164), and 46 (76.66\%) isolates amplified a cyt $b$ gene fragment of $564 \mathrm{bp}$ containing three introns (Bcbi-67/68, Bcbi-131/132 and Bcbi-164). After the PCR products were sequenced, the G143A mutation was detected only in the $564 \mathrm{bp}$ fragment of the $\mathrm{Azo}^{\mathrm{R}}$ B. cinerea isolates. This point mutation is known to affect azoxystrobin sensitivity in many fungal species. None of the $\mathrm{Azo}^{\mathrm{R}}$ isolates tested carried the Bcbi-143/144 intron in the cyt $b$ gene. None of the $1768 \mathrm{bp}$ fragments contained the G143A mutation. The allele-specific primers BcAR-F and BcAr-R produced a $260 \mathrm{bp}$ fragment only in $\mathrm{Azo}^{\mathrm{R}} B$. cinerea isolates, indicating that they all carried the G143A point mutation (Fig. 2). The G137R and F129L point mutations were not detected in any of the $B$. cinerea isolates tested. 


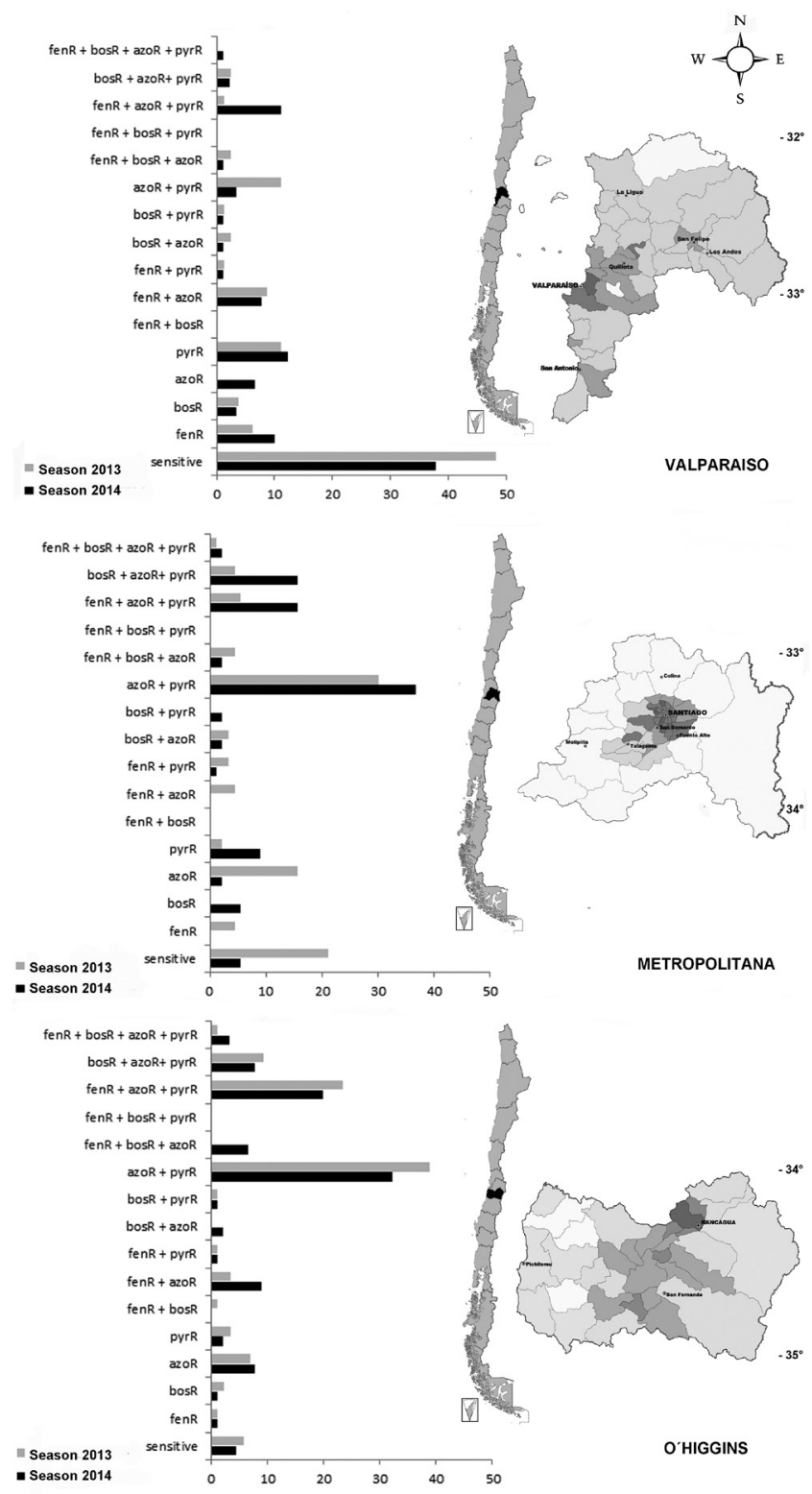

Figure 1. Frequency distribution of the different $B$. cinerea phenotype populations isolated from fifteen 'Thompson Seedless' orchards in three regions of the Central Valley of Chile.

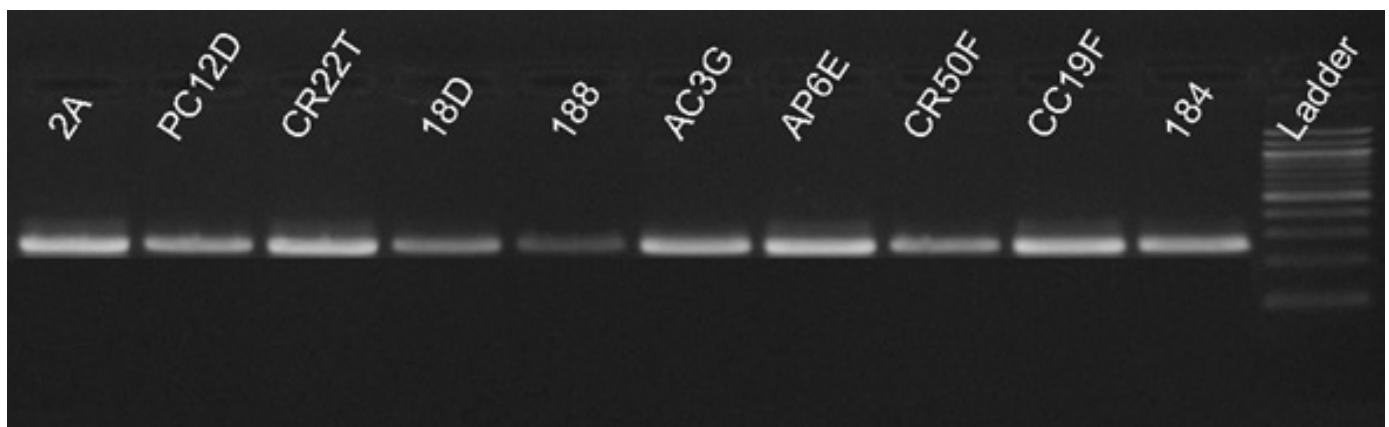

Figure 2. Example of the specific product fragments produced in selected high $\mathrm{Azo}^{\mathrm{R}}$ B. cinerea isolates carrying the G143A point mutation (260 bp). L=100 bp DNA ladder (New England Bio-Labs, Beverly, MA). 
Molecular characterization of the DNA sequence of the $s d h B$ gene from randomly selected $B^{R} s^{R}$ and $\mathrm{Bos}^{S} \mathrm{~B}$. cinerea isolates.

The analysis of the DNA sequence of the $s d h B$ gene from $\operatorname{Bos}^{\mathrm{R}} B$. cinerea isolates showed that the CAC codon (histidine) changed to TAC (tyrosine) in 12 Bos $^{\mathrm{R}}$ isolates (H272Y) and to CGC (arginine) in 18 $\mathrm{Bos}^{\mathrm{R}}$ isolates (H272R). Except for the two point mutations at position 272 in $\operatorname{Bos}^{\mathrm{R}}$ isolates, all 60 isolates analyzed had identical deduced amino acid sequences in the $s d h B$ gene. All PCR reactions with the forward primers $\mathrm{H} 272 \mathrm{R}$ and $\mathrm{H} 272 \mathrm{Y}$ and the common reverse primer H272-rev amplified a $120 \mathrm{bp}$ product. The digestion of the PCR products amplified by primer pair H272R-fw/H272-rev with HhaI resulted in two fragments of 85 and $35 \mathrm{bp}$ only for isolates possessing the H272R mutation. The digestion of the PCR products amplified by primer pair H272Y-fw/ H272-rev with EcoRV resulted in two fragments of 85 and 35 bp only for isolates that lacked the $\mathrm{H} 272 \mathrm{Y}$ mutation, whereas in isolates with the $\mathrm{H} 272 \mathrm{Y}$ mutation, the PCR products remained undigested. Results showed that $\mathrm{H} 272 \mathrm{R}$ was the predominant mutation associated with $\operatorname{Bos}^{\mathrm{R}}$ B. cinerea isolates.

Molecular characterization of erg27 gene sequences from randomly selected $\mathrm{Fen}^{R}$ and $\mathrm{Fen}^{\mathrm{S}}$ B. cinerea isolates.

Two SNPs in the erg27 gene sequence were found only in $\mathrm{Fen}^{\mathrm{R}} B$. cinerea isolates that were always associated with the replacement of a phenylalanine with serine (F412S, 90\%) or valine (F412V, 10\%) in the position 142. No mutations were associated with $\mathrm{Fen}^{\mathrm{s}}$ B. cinerea isolates.

\section{Cross-resistance relationships.}

With the exception of fludioxonil, the correlation coefficients of the $\mathrm{EC}_{50}$ values for all other fungicide combinations were medium to high, ranging from 0.48 (azoxystrobin vs. pyrimethanil, Valparaiso region) to 0.91 (fenhexamid vs. pyrimethanil, Valparaiso region), and were significant $(\mathrm{P}<0.001)$ (Table 2).

\section{Discussion}

Among the three regions in Central Chile from north to south (from Valparaiso to O'Higgins), the frequency of sensitive isolates decreased from $48.15 \%$ to $5.88 \%$ (Fig. 1). In addition, $19.77 \%$ of the isolates tested were resistant to one fungicide, $35.74 \%$ were resistant to two, $22.81 \%$ were resistant to three, and only $1.52 \%$ were resistant to four fungicides. Similar results were found by Latorre and Torres (2012), in 214 B. cinerea isolates collected from commercial vineyards with previous use of anilino-pyrimidines, DMIs, and hydroxyanilides.

Table 2. Cross-resistance patterns among azoxystrobin, boscalid, fenhexamid and pyrimethanil in Botrytis cinerea isolates from 'Thompson Seedless' orchards

\begin{tabular}{|c|c|c|c|c|c|c|c|c|c|}
\hline \multirow{3}{*}{ Region } & \multirow{3}{*}{ Fungicide } & \multicolumn{8}{|c|}{ Fungicide } \\
\hline & & \multicolumn{2}{|c|}{ azoxystrobin } & \multicolumn{2}{|c|}{ boscalid } & \multicolumn{2}{|c|}{ fenhexamid } & \multicolumn{2}{|c|}{ pyrimethanil } \\
\hline & & $r$ & $P$ & $r$ & $P$ & $r$ & $P$ & $r$ & $P$ \\
\hline \multirow{3}{*}{ Valparaíso } & azoxystrobin & - & - & 0.53 & $<0.0001$ & 0.63 & $<0.0001$ & 0.48 & $<0.0001$ \\
\hline & boscalid & - & - & - & - & 0.88 & $<0.0001$ & 0.87 & $<0.0001$ \\
\hline & fenhexamid & - & - & - & - & - & - & 0.91 & $<0.0001$ \\
\hline \multirow{3}{*}{ Metropolitana } & azoxystrobin & - & - & 0.8 & $<0.0001$ & 0.79 & $<0.0001$ & 0.7 & $<0.0001$ \\
\hline & boscalid & - & - & - & - & 0.87 & $<0.0001$ & 0.68 & $<0.0001$ \\
\hline & fenhexamid & - & - & - & - & - & - & 0.84 & $<0.0001$ \\
\hline \multirow{3}{*}{ O'Higgins } & azoxystrobin & - & - & 0.85 & $<0.0001$ & 0.87 & $<0.0001$ & 0.86 & $<0.0001$ \\
\hline & boscalid & - & - & - & - & 0.69 & $<0.0001$ & 0.58 & $<0.0001$ \\
\hline & fenhexamid & - & - & - & - & - & - & 0.86 & $<0.0001$ \\
\hline
\end{tabular}


Among the three regions, the frequency of multipleresistant $B$. cinerea phenotypes increased from $30.40 \%$ in Valparaiso to $81.70 \%$ in $\mathrm{O}^{\prime}$ Higgins (Fig. 1), indicating that the risk of development of multiple resistance in $B$. cinerea found in table grape populations in Central Chile is higher where the environmental conditions are more favorable for Botrytis infection. In O'Higgins, the most cool and wet of the three regions, it is common for table grape growers to apply 6-7 fungicide sprays per season. In Valparaiso, the most warm and dry of the three regions, only 4-5 applications are required. These differences modulate the selective pressure exerted by the fungicides on the $B$. cinerea populations in the different regions.

Six of $10 \mathrm{~B}$. cinerea isolates collected in the three regions showed resistance to azoxystrobin. In the sensitivity test, all $336 \mathrm{Azo}^{\mathrm{R}}$ isolates showed high resistance to azoxystrobin, ranging from 102 to $>1000 \mu \mathrm{g} \mathrm{ml}^{-1}$. Similar results were reported by Yin et al. (2012).

Among the 60 randomly selected isolates, only the $\mathrm{Azo}^{\mathrm{R}}$ isolates harbored the G143A point mutation, in agreement with many previous studies (Yin et al., 2012). None of the $\mathrm{Azo}^{\mathrm{R}}$ isolates tested carried the Bcbi-143/144 intron; the presence of this intron in the $c y t b$ gene prevents the occurrence of G143Amediated resistance (Grasso et al., 2006; Yin et al., 2012) in many fungal species. Moreover, as only $23.3 \%$ of the $60 \mathrm{~B}$. cinerea isolates contained the Bcbi-143/144 intron, this low percentage indicates that B. cinerea populations from 'Th. Seedless' in Chile hold a high inherent risk of development of resistance to QoI fungicides.

In the present study, we detected an unpredictably high frequency of pyrimethanil-resistant $B$. cinerea isolates: five out of $10 \mathrm{~B}$. cinerea isolates collected showed resistance to pyrimethanil with $\mathrm{EC}_{50}$ values from 10.2 to $62.1 \mu \mathrm{g} \mathrm{ml}^{-1}$. Among the anilinopyrimidine fungicides, cyprodinil was used for a limited number of seasons for gray mold control in table grapes in Chile, until resistant popula- tions emerged. Latorre et al. (2002) reported that $38.5 \%$ of the $B$. cinerea population was resistant to anilino-pyrimidines in vineyards following four fungicide applications in a two-year period. Afterwards, in a survey conducted between 2007 and 2011, the frequency of anilino-pyrimidineresistant isolates increased from $45 \%$ to $77.4 \%$ (Latorre and Torres, 2012). Even though in the last decade, Switch ${ }^{\circledR}$ (cyprodinil + fludioxonil) has been the most widely used botryticide in table grape Botrytis control, it is likely that selection for cyprodinil resistance has occurred in Chile despite the presence of fludioxonil in the sprayed fungicides. On the other hand, it would also be due to the use of other anilino-pyrimidine fungicides registered for gray mold control in table grapes.

The resistance to AP fungicides is stable and without fitness costs because it does not affect the vital components of the fungal cells; several studies have documented the existence of strong cross-resistance between AP fungicides in $B$. cinerea (Zhang et al., 2009).

Fenhexamid has been available for use on table grapes and vegetable crops since 1999 and has become a key component of gray mold disease management in Chile. Despite the fact that $B$. cinerea strains with reduced sensitivity to fenhexamid have been detected in Chile, it did not lead to a total field control failure (Esterio et al., 2007, 2012).

Four of $10 \mathrm{~B}$. cinerea isolates collected in the three regions showed resistance to fenhexamid, and in the sensitivity test, the $\mathrm{EC}_{50}$ value of 149 $\mathrm{Fen}^{\mathrm{R}}$ isolates ranged from 1.25 to $299 \mu \mathrm{g} \mathrm{ml}^{-1}$. After partial sequencing of the $\operatorname{erg} 27$ gene in the randomly selected $\mathrm{Fen}^{\mathrm{R}}$ B. cinerea isolates, $90 \%$ $(\mathrm{n}=27)$ possessed the $\mathrm{F} 412 \mathrm{~S}$ substitution, and $10 \%$ $(\mathrm{n}=3)$ possessed the F412V substitution. The F412S and $\mathrm{F} 412 \mathrm{~V}$ mutations had already been reported in Chilean B. cinerea-resistant isolates from table grapes (Esterio et al., 2012). Reduced survival in the field has been reported for fenhexamidresistant strains. The effect of F412 mutations in the high $\mathrm{Fen}^{\mathrm{R}}$ B. cinerea isolates would impact 
their survival capacity, limiting their dispersal and persistence, particularly when overwintering under field conditions (Billard et al., 2012).

Boscalid is a recently introduced member of SDHIs, which are effective in controlling diseases caused by $B$. cinerea. In the present study, two out of $10 \mathrm{~B}$. cinerea isolates collected in the three regions showed resistance to boscalid. The $\mathrm{EC}_{50}$ values ranged from 15.04 to $>1000 \mu \mathrm{g} \mathrm{ml}^{-1}$. Our results showed that $\mathrm{H} 272 \mathrm{R}$ was the predominant mutation associated with the randomly selected $\mathrm{Bos}^{\mathrm{R}} B$. cinerea isolates; $60 \%(\mathrm{n}=18)$ possessed the $\mathrm{H} 272 \mathrm{R}$ substitution and $40 \%(\mathrm{n}=12)$ possessed the $\mathrm{H} 272 \mathrm{Y}$ substitution, in agreement with previous studies conducted on grapevines where $s d h B$ $\mathrm{H} 272 \mathrm{Y}$ and $s d h B$ H272R were the most frequent mutations in $B$. cinerea populations treated with boscalid (Esterio, 2014; Veloukas et al., 2011; Yin et al., 2011). In Champagne vineyards (Walker et al. 2013), due to the availability of other classes of botryticides and the limited use of SDHIs, boscalid resistance frequency has not become widespread, and the emergence of the moderately resistant mutants $s d h B \mathrm{H} 272 \mathrm{Y}$ and $s d h B \mathrm{H} 272 \mathrm{R}$ has been favored over more resistant mutants.

In Chile, Piqueras et al. (2014) reported a high boscalid resistance in Botrytis isolates associated with the H272L point mutation. Esterio et al. (2015) reported the detection of the H272R/Y/L and $\mathrm{P} 255 \mathrm{~L} / \mathrm{H}$ point mutations in table grapes at frequencies of $52.8 \%, 35.42 \%, 2.1 \%, 6.25 \%$ and $4.16 \%$, respectively. The introduction of new SDHI fungicides in Chile, such as fluopyram, may modify the structure of local $B$. cinerea populations. In fact, no cross-resistance has been detected between pyridine-carboxamides (e.g., boscalid) and pyridinyl-ethyl-benzamides (e.g., fluopyram) in $s d h B \mathrm{H} 272 \mathrm{Y}$ and $s d h B \mathrm{H} 272 \mathrm{R}$ mutants; this new family of fungicides may therefore be very useful for the control of these prevalent mutants (Veloukas and Karaoglanidis, 2012).

In the present study, azoxystrobin and pyrimethanil resistance frequencies in $B$. cinerea isolates collected from the three regions were only $7.0 \%$ (35 out of 526 isolates), but the frequency of the double-resistant $\mathrm{Azo}^{\mathrm{R}}+\mathrm{Pyr}^{\mathrm{R}}$ phenotype reached $25.4 \%$ (134 out of 526 isolates). The development of multiple-resistance to chemically unrelated fungicides has been reported in different $B$. cinerea populations (Weber, 2011).

On the other side, in the Metropolitana and O'Higgins regions, the detected frequencies of the multiple-resistant $B$. cinerea phenotypes $\mathrm{Azo}^{\mathrm{R}}+\mathrm{Pyr}^{\mathrm{R}}+\mathrm{Fen}^{\mathrm{R}}$ and $\mathrm{Azo}^{\mathrm{R}}+\mathrm{Pyr}^{\mathrm{R}}+\mathrm{Bos}^{\mathrm{R}}$ were only $10.56 \%$ and $10 \%$, and $21.7 \%$ and $8.5 \%$, respectively. The frequencies of these two $B$. cinerea multiple-resistant phenotypes $\left(\mathrm{Azo}^{\mathrm{R}}+\mathrm{Pyr}^{\mathrm{R}}+\mathrm{Fen}^{\mathrm{R}}\right.$ and $\left.\mathrm{Azo}^{\mathrm{R}}+\mathrm{Pyr}^{\mathrm{R}}+\mathrm{Bos}^{\mathrm{R}}\right)$ were much lower than the dual $A z o^{\mathrm{R}}+\mathrm{Pyr}^{\mathrm{R}}$ B. cinerea phenotype frequency, the $\mathrm{Azo}^{\mathrm{R}}+\mathrm{Pyr}^{\mathrm{R}}+\mathrm{Bos}^{\mathrm{R}}$ phenotype being the least frequent in both regions. Additionally, in the present study, a very low multiple-resistant $\mathrm{Azo}^{\mathrm{R}}+\mathrm{Pyr}^{\mathrm{R}}+\mathrm{Fen}^{\mathrm{R}}+\mathrm{Bos}^{\mathrm{R}}$ phenotype frequency was detected (Fig. 1). These results suggest that the increase in the fitness cost observed in this study in the $B$. cinerea multiple-resistant phenotypes may be due to the simultaneous presence of the erg27 (F412S or F412V) and/or $s d h \mathrm{~B}$ (H272R/Y) gene mutations (Fig. 1). Veloukas et al. (2014) reported that most of the isolate groups with multiple-resistance to SDHIs and QoIs, associated with different $s d h B$ mutations and the G143A mutation, suffered significant fitness costs.

In the present study, no fludioxonil-resistant isolates were detected among the 526 isolates tested using inhibition growth assays, and the $\mathrm{EC}_{50}$ values ranged from 0.01 to $0.27 \mu \mathrm{g} \mathrm{ml}^{-1}$. These results indicate that fludioxonil still holds a high potential for $B$. cinerea control in table grapes in Chile. Similar results were found by Myresiotis et al. (2007), who did not find fludioxonil-resistant isolates among the B. cinerea populations resistant to azoxystrobin and pyrimethanil, while few fludioxonil-resistant populations from strawberry fields were observed by Fernández-Ortuño et al. (2013). High levels of fludioxonil resistance have only been detected in laboratory mutants and were linked to a decrease 
in fitness, probably due to the polygenic control of the resistance, as shown by Vignutelli et al. (2002), or the reduced competitive ability of the fludioxonil-resistant strains compared with the wild-type strains (Ziogas and Kalamarakis, 2001). The development of fludioxonil resistance in the field might have detrimental effects on the survival of the pathogen.

Maintaining the effectiveness of fludioxonil, fenhexamid and boscalid against $B$. cinerea by delaying resistance development, and delaying resistance evolution to QoIs and APs by limiting the number of fungicide applications in table grapes for gray mold control programs in the Central Valley of Chile, should be required for the successful control of the disease. Resistance monitoring is therefore essential to detect the emergence of new resistant phenotypes on the 'Th. Seedless' B. cinerea populations.

To maintain the effectiveness of the available fungicides for the future, strict resistance management strategies are required. These include good crop management and sanitation measures to reduce the risk of gray mold infection, such as suitable use of nitrogen fertilizers, restraint of canopy humidity through manipulations, adequate cluster thinning, and removal of infected fruits and inoculum reservoirs. To limit selection for resistance, rotation between fungicides of different classes and limitation of treatments with the same class of compounds to one per season should be mandatory, with a possible exception for fludioxonil, which has a low risk of specific resistance. However, these rules are often broken by table grape growers, and fungicides are often used excessively. One of the reasons the rules are broken is the maximum number of detectable pesticide residues on the fruit that are imposed by international retailers, which limits the available options for fungicide rotations. Furthermore, fludioxonil and SDHIs are sold in Chile mixed with other fungicides, restricting the flexibility to optimize the spraying programs. The availability of quick cultivation-based and molecular tests allows a rapid evaluation of resistance, including the prevalence of resistance mutations before and after treatments, to help devise locally adapted resistance management programs.

\section{Acknowledgments}

Research was support by InnovaChile de CORFO grant $\mathrm{N}^{\circ} 11 \mathrm{BPC}-9947$.

\section{Resumen}

M. Esterio, C. Copier, A. Román, M.J. Araneda, M. Rubilar, I. Pérez, y J. Auger. 2017. Frecuencia de poblaciones de Botrytis cinerea resistentes a fungicidas en uva de mesa 'Thompson Seedless' en el Valle Central de Chile. Cien. Inv. Agr. 44(3): 295-306. Durante las temporadas de crecimiento 2013 y 2014, se colectaron 526 aislados de Botrytis cinerea desde flores naturalmente infectadas, en quince huertos de uva de mesa 'Thompson Seedless', de tres regiones del Valle Central de Chile (Valparaíso, Metropolitana y O’Higgins). Se evaluó la sensibilidad de todos los aislados colectados a: azoxystrobin, boscalid, fenhexamid, fludioxonil y pyrimetanil. 106 aislados $(20,15 \%)$ fueron sensibles a todos los fungicidas evaluados con una frecuencia (norte a sur) de 48,15\%, 21,1\% y 5,88\%, respectivamente. Cuatrocientos veinte aislados fueron resistentes a uno o varios fungicidas, de los cuales, 134 (25,4\%) fueron simultaneamente resistentes a azoxystrobin y pyrimetanil. No se detectaron aislados resistentes a fludioxonil, lo que indica que este fungicida mantiene un adecuado potencial de control de la pudrición gris en uva de mesa en los huertos muestreados. De 30 aislados de $B$. cinerea resistentes a azoxystrobin $\left(\mathrm{Azo}^{\mathrm{R}}\right)$ y 30 sensibles a azoxystrobin $\left(\mathrm{Azo}^{\mathrm{S}}\right)$, arbitrariamente seleccionados, solo 
los aislados $\mathrm{Azo}^{\mathrm{R}}$ portaban la mutación G143A y de acuerdo a la estructura del gen $c y t b$, el tercer intron Bcbi 143/144 solo fue detectado en los aislados Azos. De 30 aislados de B. cinerea resistentes a boscalid $\left(\mathrm{Bos}^{\mathrm{R}}\right)$ y 30 sensibles a boscalid $\left(\mathrm{Bos}^{\mathrm{S}}\right)$, arbitrariamente seleccionados, las mutaciones H272R and H272Y se encontraron asociadas al gen $s d h B$ solo en los aislados $\operatorname{Bos}^{\mathrm{R}}$. La secuenciación parcial del gen erg 27 en los 30 aislados resistentes a fenhexamid $\left(\mathrm{Fen}^{\mathrm{R}}\right)$, permitió detectar, solo en los aisladdos FenR, las mutaciones F412S y F412V. Los resultados de este estudio constituyen una contribución al conocimiento de la resistencia de $B$. cinerea a los principales fungicidas utilizados en el control de la pudrición gris en uva de mesa en el Valle Central de Chile, particularmente en lo que se refiere a la predominancia de las mutaciones asociadas a poblaciones de $B$. cinerea resistentes.

Palabras clave: Anilinopirimidinas, fenilpirroles, inhibidores de la biosíntesis del esterol clase III, inhibidores de succinate dehidrogenasa, inhibidores externos de quinona, pudrición gris, resistencia multiple.

\section{References}

Bardas, G.A., T. Veloukas, O. Koutita, and G.S. Karaoglanidis. 2010. Multiple resistance of Botrytis cinerea from kiwifruit to SDHIs, QoIs and fungicides of other chemical groups. Pest. Manag. Sci. 66:967-973.

Billard, A., S. Fillinger, P. Leroux, H. Lachaise, R. Beffa, and D. Debieu. 2012. Strong resistance to the fungicide fenhexamid entails a fitness cost in Botrytis cinerea, as shown by comparisons of isogenic strains. Pest. Manag. Sci. 68:684-691.

De Miccolis Angelini, R.M., C. Rotolo, M. Masiello, S. Pollastro, H. Ishii, and F. Faretra. 2012. Genetic analysis and molecular characterization of laboratory and field mutants of Botryotinia fuckeliana (Botrytis cinerea) resistant to QoI fungicides. Pest. Manag. Sci. 68:1231-1240.

De Miccolis Angelini, R.M., C. Rotolo, M. Masiello, D. Gerin, S. Pollastro, and F. Faretra. 2014. Occurrence of fungicide resistance in populations of Botryotinia fuckeliana (Botrytis cinerea) on table grape and strawberry in southern Italy. Pest. Manag. Sci. 70:1785-1796.

Di Rienzo, J.A., F. Casanoves, M.G. Balzarini, L. González, M. Tablada, and C.W. Robledo. 2014. InfoStat versión 2014. Grupo InfoStat, Facultad de Ciencias Agropecuarias, Universidad Nacional de Córdoba, Argentina.

Esterio, M., J. Auger, C. Ramos, and H. García. 2007. First report of fenhexamid resistant iso- lates of Botrytis cinerea on grapevine in Chile. Plant Dis. 91(6):768.

Esterio, M., C. Ramos, A.S. Walker, S. Fillinger, P. Leroux, and J. Auger. 2012. Phenotypic and genetic characterization of $B$. cinerea Chilean isolates of different levels of fenhexamid sensitivity. Phytopathol. Mediterr. 50(3):414-420.

Esterio, M., M.J. Araneda, A. Román, L. Pizarro, C. Copier, and J. Auger. 2015. First Report of Boscalid Resistant Botrytis cinerea Isolates Carrying the Mutations H272R, H272Y, P225L, and P225H from Table Grape in Chile. Plant Dis. 99(6):891.

Fernández-Ortuño, D., F.P. Chen, and G. Schnabel. 2013. Resistance to cyprodinil and lack of fludioxonil resistance in Botrytis cinerea isolates from strawberry in North and South Carolina. Plant Dis. 97:81-85.

Fillinger, S., P. Leroux, C .Auclair, C. Barreau, C. Al Hajj, and D. Debieu. 2008. Genetic analysis of fenhexamid-resistant field isolates of the phytopathogenic fungus Botrytis cinerea. Antimicrob. Agents Chemother. 52:3933-3940.

Grasso, V., S. Palermo, H. Sierotzki, A. Garibaldi, and U. Gisi. 2006. Cytochrome b gene structure and consequences tor resistance to Qo inhibitor fungicides in plant pathogens. Pest. Manag. Sci. 62:465-472.

Ishii, H., J. Fountaine, W.H. Chung, M. Kansako, K. Nishimura, K. Takahashi, and M. Oshima. 2009. Characterization of QoI-resistant field isolates of 
Botrytis cinerea from citrus and strawberry. Pest. Manag. Sci. 65:916-922.

Jiang, J., L. Ding, T.J. Michailides, H. Li, and Z. Ma. 2009. Molecular characterization of field azoxystrobin-resistant isolates of Botrytis cinerea. Pest. Biochem. Physiol. 93:72-76.

Latorre, B.A. and R. Torres. 2012. Prevalence of isolates of Botrytis cinerea resistant to multiple fungicides in Chilean vineyards. Crop Prot. 40: 49-52.

Latorre, B.A., I. Spadaro, and M.E. Rioja. 2002. Occurrence of resistant strains of Botrytis cinerea to anilinopyrimidine fungicides in table grapes in Chile. Crop Prot. 21:957-961.

Leroux, P., R. Fritz, D. Debieu, C. Albertini, C. Lanen, J. Bach, M. Gredt, and F. Chapeland. 2002. Mechanisms of resistance to fungicides in field strains of Botrytis cinerea. Pest. Manag. Sci. 58:876-888.

Moyano, C., V. Gómez, and P. Melgarejo. 2004. Resistance to pyrimethanil and other fungicides in Botrytis cinerea populations collected on vegetable crops in Spain. J. Phytopathol. 152:484-490.

Myresiotis, C.K., G.S. Karaoglanidis, and K. Tzavella-Klonari. 2007. Resistance of Botrytis cinerea isolates from vegetable crops to anilinopyrimidine, phenylpyrrole, hydroxyanilide, benzimidazole, and dicarboximide fungicides. Plant Dis. 91:407-413.

ODEPA. 2016. Avance por producto de exportaciones/importaciones. http://www.odepa.cl/avancepor-producto-de-exportacionesimportaciones/ (accessed 14 Jul. 2016).

Piqueras, C.M., D. Herrera, and B.A. Latorre. 2014. First Report of High Boscalid Resistance in Botrytis cinerea Associated with the H272L Mutation in Grapevine in Chile. Plant Dis. 98(10):1441.

Veloukas, T., M. Leroch, M. Hahn, and G.S. Karaoglanidis. 2011. Detection and molecular characterization of boscalid-resistant Botrytis cinerea isolates from strawberry. Plant Dis. 95:13021307.

Veloukas ,T., and G.S. Karaoglanidis. 2012. Biological activity of the succinate dehydrogenase inhibitor fluopyram against Botrytis cinerea and fungal baseline sensitivity. Pest. Manag. Sci. 68:858-864.

Veloukas, T., P. Kalogeropoulou, A.N. Markoglou, and G.S. Karaoglanidis. 2014. Fitness and competitive ability of Botrytis cinerea field isolates with dual resistance to SDHI and QoI fungicides, associated with several $s d h B$ and the $c y t$ b G143A mutations. Phytopathology 104:347-356.

Vignutelli, A., M. Hilber-Bodmer, and U.W. Hilber. 2002. Genetic analysis of resistance to the phenylpyrrole fludioxonil and the dicarboximide vinclozoline in Botryotinia fuckeliana (Botrytis cinerea). Mycol. Res. 106:329-335.

Walker, A.S., A. Micoud, F. Rémuson, J. Grosman, M. Gredt, and P. Leroux. 2013. French vineyards provide information that opens ways for effective resistance management of Botrytis cinerea (grey mould). Pest. Manag. Sci. 69: 667-678.

Weber, R.W.S. 2010. Occurrence of Hyd R3 fenhexamid resistance among Botrytis isolates in northern German soft fruit production. J. Plant Dis. Prot. 117:177-179.

Weber, R.W.S. 2011. Resistance of Botrytis cinerea to multiple fungicides in Northern German small-fruit production. Plant Dis. 95:1263-1269.

Weber, R.W.S., and M. Hahn. 2011. Rapid and simple method for determining fungicide resistance in Botrytis. J. Plant Dis. Prot. 118: 17-25.

Yin, Y.N., Y.K. Kim, and C.L. Xiao. 2011. Molecular characterization of boscalid resistance in field isolates of Botrytis cinerea from apple. Phytopathology 101:986-995.

Yin, Y.N., Y.K. Kim, and C.L. Xiao. 2012. Molecular characterization of pyraclostrobin resistance and structural diversity of the cytochrome $b$ gene in Botrytis cinerea from apple. Phytopathology 102:315-322.

Zhang, C.Q., J.L. Hu, F.L. Wei, and G.N. Zhu. 2009. Evolution of resistance to different classes of fungicides in Botrytis cinerea from greenhouse vegetables in eastern China. Phytoparasitica 37:351-359.

Ziogas, B.N. and A.E. Kalamarakis. 2001. Phenylpyrrole fungicides: Mitotic instability in Aspergillus nidulans and resistance in Botrytis cinerea. J. Phytopathol. 149:301-308. 